\title{
Pengaruh kepuasan kerja dan persepsi pada iklim organisasi terhadap perilaku kewargaan organisasi karyawan PT. Garuda Indoneisa, (Persero), Tbk. Cabang Denpasar
}

\author{
Komang Mega Trisnayani dan Naomi Vembriati \\ Program Studi Sarjana Psikologi, Fakultas Kedokteran, Universitas Udayana \\ naomi.vembriati@unud.ac.id
}

\begin{abstract}
Abstrak
Karyawan adalah salah satu kunci sukses perusahaan di tengah persaingan dalam era globalisasi sehingga penting bagi pemilik usaha memiliki karyawan dengan kinerja yang baik. Salah satunya dengan menunjukkan perilaku kewargaan organisasi di tempat kerja. Perilaku Kewargaan Organisasi adalah suatu bentuk perilaku yang merupakan pilihan dan inisiatif individual yang tidak berkaitan dengan sistem reward formal organisasi tetapi dapat meningkatkan efektivitas organisasi. Perilaku kewargaan organisasi dipengaruhi oleh kepuasan kerja. Karyawan yang puas cenderung akan memberikan pelayanan dan kinerja yang optimal, salah satunya adalah PKO. Selain kepuasan kerja, persepsi pada iklim organisasi juga berperan dalam memunculkan PKO. Jika karyawan mempersepsikan iklim organisasi secara positif maka hal tersebut dapat menumbuhkan semangat kerja sekaligus mendorong karyawan menampilkan PKO. Tujuan dari penelitian ini adalah untuk memperoleh bukti empiris mengenai pengaruh kepuasan kerja dan persepsi pada iklim organisasi terhadap perilaku kewargaan organisasi karyawan PT. Garuda Indonesia (Persero), Tbk cabang Denpasar. Teknik sampling dalam penelitian ini adalah sampling jenuh dengan menggunakan seluruh pegawai tetap berjumlah 71 orang. Penelitian ini merupakan penelitian kuantitatif dengan teknik pengumpulan data menggunakan kuesioner/angket, sedangkan analisis data dilakukan dengan analisis regresi linier berganda. Hasil dari penelitian ini ialah : 1) Kepuasan kerja dan persepsi pada iklim organisasi memiliki kontribusi terhadap kemunculan PKO dengan persentase sebesar 50,5\% dengan taraf signifikansi 0,000 (p<0,05). 2) Kepuasan kerja tidak berkontribusi secara signifikan terhadap PKO dengan nilai signifikansi sebesar $0,166(\mathrm{p}>0,05)$, 3) Terdapat kontribusi yang signifikan antara persepsi pada iklim organisasi terhadap PKO dengan nilai signifikansi sebesar $0,000(p<0,05)$.
\end{abstract}

Kata kunci : Kepuasan kerja, perilaku kewargaan organisasi, persepsi pada iklim organisasi.

\begin{abstract}
Employees are one of the keys to a company's success in the midst of competition in the era of globalization. So it is important for business owners to have employees with good performance. One of them is by demonstrating organizational citizenship behavior in the workplace. Organizational Citizenship Behavior is a form of individual choice and initiative that is not related to the formal reward system of the organization but can improve organizational effectiveness. Organizational citizenship behavior is influenced by job satisfaction. Satisfied employees tend to provide optimal service and performance, one of which is OCB. In addition to job satisfaction, perceptions of the organizational climate also play a role in raising OCB. If employees perceive the organization's climate positively, it can foster working spirit while encouraging employees to display OCB. The purpose of this study was to obtain empirical evidence about the effect of job satisfaction and perceptions of the organizational climate to OCB on employees of PT. Garuda Indonesia (Persero), Tbk Denpasar branch. The sampling technique in this study is saturated sampling using all 71 permanent employees. This research is a quantitative study with data collection techniques using questionnaires / questionnaires, while data analysis is done by multiple linear regression analysis. The result of this research are: 1) Job satisfaction and perception on organizational climate have contribution to the appearance of OCB with percentage of $50,5 \%$ with significance level $0,000(\mathrm{p}<0,05)$. 2) Job satisfaction does not contribute significantly to OCB with a significance value of $0.166(\mathrm{p}>0.05)$; 3$)$ There is a significant contribution between perceptions on organizational climate towards OCB with a significance value of $0.000(\mathrm{p}<0,05)$.
\end{abstract}

Keywords: Job satisfaction, organizational citizenship behavior, perception on organizational climate. 


\section{K. M. TRISNAYANI \& NAOMI VEMBRIATI}

\section{LATAR BELAKANG}

Salah satu aset berharga milik perusahaan adalah SDM, karena suatu organisasi bisa dikatakan berjalan efektif dan berhasil apabila SDM yang ada dalam organisasi tersebut memiliki kualitas kinerja yang tinggi, salah satunya adalah Perilaku Kewargaan Organisasi (PKO)/Organizational Citizenship Behavior (OCB). Karyawan dengan tingkat $\mathrm{PKO}$ yang tinggi, akan membantu suatu organisasi mencapai produktivitas yang tinggi. Definisi Perilaku Kewargaan Organisasi (PKO) adalah semangat kerja dan motivasi tinggi untuk bekerja melampaui kewajiban pekerjaan formalnya dan secara sukarela memberikan waktu dan tenaganya untuk kesuksesan pelaksanaan tugas (Saptoani, 2011).

Peran atau tugas seorang karyawan telah digariskan secara formal pada deskripsi pekerjaan. Pada saat keadaan normal, semua karyawan telah maksimal bekerja sesuai dengan deskripsi pekerjaannya, sehingga kinerja organisasi akan maksimal pula. Namun dalam kenyataannya tidak selalu kondisi normal itu berjalan sebagaimana mestinya. Bila terjadi gangguan pada kinerja seseorang karyawan di dalam sebuah kerja tim, maka untuk menjaga sistem pekerjaan tetap berjalan secara keseluruhan diperlukan kesediaan karyawan lainnya untuk berperan ekstra mengambil alih pekerjaan demi terselesaikannya tugas-tugas dalam tim meski telah ada dalam deskripsi pekerjaannya. Organ (1997) mendefinisikan PKO sebagai suatu perilaku yang merupakan pilihan dan inisiatif individual yang dapat meningkatkan produktivitas organisasi, namun tidak berkaitan dengan sistem reward formal. Hal ini berarti bahwa perilaku tersebut tidak termasuk ke dalam deskripsi kerja karyawan sehingga apabila karyawan tidak menampilkan perilaku tersebut, karyawan tidak akan mendapat penghargaan maupun hukuman. Organisasi akan dapat menghasilkan kinerja dengan baik bilamana karyawan tidak hanya melakukan tugas pokoknya saja, namun juga mau melakukan tugastugas ekstra seperti mau menolong sesama rekan kerja yang akan membantu menyebarkan sikap kerja terbaik ke seluruh unit kerja sehingga akan meningkatkan produktivitas.

Perilaku kewargaan organisasi tidak terdapat pada deskripsi pekerjaan karyawan, tetapi sangat diharapkan, karena mendukung peningkatan efektivitas dan kelangsungan hidup organisasi, khususnya dalam lingkungan bisnis yang persaingannya semakin tajam. Hal ini sejalan dengan pendapat dari Robbins dan Judge (2008) yang menyatakan bahwa organisasi yang memiliki karyawan dengan PKO yang tinggi akan menunjukkan kinerja yang lebih optimal. Pernyataan tersebut didukung oleh hasil penelitian oleh Gunawan, Solang dan Kartika (2013) terhadap karyawan tetap divisi Front Office hotel Sheraton Surabaya. Penelitian tersebut menunjukkan bahwa peranan PKO sangat diperlukan untuk meningkatkan kinerja karyawan yang dapat berdampak positif terhadap kepuasan konsumen. Karyawan dengan kinerja yang baik dapat memberikan totalitas pelayanan terhadap pelanggan dan dapat mencapai kepuasan konsumen. Oleh karena itu perusahaan dapat mencapai produktivitas secara optimal.

Berdasarkan hasil studi pendahuluan melalui wawancara yang dilakukan dengan karyawan PT. Garuda Indonesia (Persero), Tbk cabang Denpasar, diperoleh gambaran mengenai PKO pada karyawan. Ketiga subjek yang diwawancarai telah menunjukkan PKO ditempat kerja diantaranya komitmen untuk memberikan layanan terbaik untuk konsumen, menerapkan kedisiplin dan kerja keras selama bekerja tanpa diawasi oleh atasan, berpartisipasi aktif ketika ada rapat penting dan kegiatan yang diadakan perusahaan, menjaga hubungan yang harmonis dan saling mendukung dengan sesama rekan kerja serta menunjukkan sikap toleransi responden terhadap ketidaknyaman situasi yang terjadi di perusahaan tanpa mengeluh. Pada saat melakukan wawancara ketiga responden menyebutkan bahwa perusahaan sedang mengalami krisis sehingga terjadi perubahan kebijakan sementara. Namun ketiga responden tetap menjalani dan menghormati keputusan pihak perusahaan dan tetap bekerja dengan optimal (Trisnayani, 2017)

Perilaku Kewargaan Organisasi berkaitan dengan tingkat absensi dan keinginan keluar yang lebih rendah pada karyawan, sehingga organisasi akan dapat mengurangi biaya dan meningkatkan produktivitas, efisiensi, dan kepuasan pelanggan yang akan berpengaruh terhadap pendapatan perusahaan (Zhang, 2011). Menurut Triyanto (2009) karyawan yang memiliki PKO akan memiliki loyalitas yang tinggi terhadap organisasi tempatnya bekerja, serta dengan sendirinya akan merasa nyaman dan aman terhadap pekerjaannya.

Perilaku Kewargaan Organisasi merupakan hal yang penting dalam organisasi, sehingga perusahaan perlu untuk mempertimbangkan variabel-variabel yang dapat membentuk PKO. Peningkatan PKO dalam organisasi dapat diidentifikasi oleh berbagai faktor. Menurut Organ, Podsakoff dan MacKenzie (2006) terdapat dua faktor utama yang mempengaruhi PKO diantaranya faktor internal dan eksternal. Faktor internal berasal dari diri karyawan sendiri, salah satunya adalah kepuasan kerja. 
Menurut Titisari (2014) kepuasan kerja merupakan sikap individu yang berasal dari persepsi mereka tentang pekerjaannya. Kepuasan kerja berpangkal dari aspek kerja, seperti upah, kesempatan promosi, pengawasan serta hubungan dengan rekan kerja. Ketika karyawan merasakan kepuasan terhadap pekerjaan yang dilakukannya, maka karyawan tersebut akan bekerja secara maksimal dalam menyelesaikan pekerjaannya, bahkan melakukan beberapa hal yang mungkin di luar tugasnya. Kepuasan kerja secara konsisten terbukti berhubungan erat dengan PKO (Wulandari, 2015; Triyanto, 2009; Soegandhi, 2013; Yuniar, Nurtjahjanti \& Rusmawati, 2011; Putra \& Dewi, 2016; Udayana \& Suwandana, 2017; Waspodo \& Minandaniati, 2012)

Pegawai yang memiliki PKO akan mampu mengendalikan perilakunya sendiri atau memilih perilaku yang sesuai untuk kepentingan organisasi. Kondisi ini terjadi jika pegawai memiliki persepsi positif pada organisasinya, termasuk pada iklim dalam organisasi tersebut. Gordon (dalam Prihatsanti \& Dewi, 2010) menjelaskan hubungan antara iklim organisasi (iklim sekolah) dengan PKO, yaitu jika iklim organisasi dipersepsikan secara positif maka PKO akan muncul. Persepsi pada iklim organisasi secara konsisnten terbukti berhubungan erat dengan PKO (Lubis, 2015; Prihatsanti \& Dewi, 2015; Chairunnisa, 2017; Mahendra \& Surya, 2016; Veera, 2014; Waspodo \& Minandaniati, 2012).

Setiap organisasi akan memiliki iklim organisasi yang berbeda. Keanekaragaman pekerjaan yang dirancang di dalam organisasi, atau sifat individu yang ada akan menggambarkan perbedaan tersebut. Iklim organisasi penting untuk diciptakan karena merupakan persepsi seseorang tentang apa yang diberikan oleh organisasi. Kinerja yang tinggi dapat tercipta apabila karyawan merasa senang dan nyaman dalam bekerja. Oleh karena itu karyawan akan merasakan bahwa mereka mendapatkan apa yang diperolehnya dan dengan kinerjanya yang tinggi tersebut perusahaan dapat memperoleh keuntungan yang diinginkan (Lubis, 2015).

Menurut Appelbaum (dalam Kusumajanti, 2014) karyawan dikatakan mempunyai PKO yang baik jika menunjukkan beberapa perilaku diantaranya membuat pernyataan konstruktif tentang organisasi dan kelompok kerjanya, menghindari konflik yang tidak perlu, membantu karyawan lain dalam satu tim, mengajukan diri untuk pekerjaan ekstra, menghormati semangat dan isi peraturan yang dimiliki organisasi, dan dengan besar hati mentolerir kerugian dan gangguan terkait pekerjaan yang kadang terjadi. PT.
Garuda Indonesia (Persero), Tbk adalah BUMN yang mencerminkan indiktor PKO tersebut, salah satu indikator yang terpenuhi ialah mendapatkan penilaian yang baik konsumen. Konsumen yang menggunakan layanan jasa penerbangan PT. Garuda Indonesia (Persero), Tbk merasa puas dengan pelayanan yang diberikan ditunjukkan dengan serangkaian penghargaan yang didapatkan, diantaranya : Garuda Indonesia berhasil menempati peringkat pertama sebagai maskapai yang paling dicintai di seluruh dunia dalam hasil survei SkyTrax, Garuda Indonesia berhasil masuk 10 besar maskapai terbaik di seluruh dunia, Garuda Indonesia adalah satu-satunya maskapai berbintang lima di Indonesia (anonim, 2018). Penelitian ini dilakukan untuk memperoleh gambaran mengenai PKO karyawan Garuda Indonesia Cabang Denpasar serta variabel yang berperan untuk memunculkan PKO pada karyawan, dalam hal ini adalah kepuasan kerja dan persepsi pada iklim organisasi.

Karyawan PT. Garuda Indonesia (Persero) Tbk. Cabang Denpasar dipilih sebagai sampel penelitan karena adanya fenomena khusus terkait PKO bila dikaitkan dengan agama dan budaya masyarakat Bali salah satunya adat menyama braya (gotong royong). Karyawan yang beragama Hindu dan merupakan warga Bali berjumlah 45 orang dari jumlah total keseluruhan karyawan PT. Garuda Indonesia (Persero) Tbk. Cabang Denpasar. Asumsi penelitian ini bahwa, karyawan Garuda Indonesia yang beragama Hindu dan mengikuti adat istiadat budaya Bali akan lebih banyak mengambil cuti pada saat upacara keagamaan seperti ngaben (kremasi), pernikahan, dan piodalan (hari jadi sebuah tempat suci), sehingga pada saat karyawan yang bersangkutan cuti, diperlukan kesediaan karyawan lainnya untuk menggantikan rekan kerjanya yang berhalangan hadir agar pelayanan terhadap pengguna jasa tetap berjalan dengan baik. Selain itu, pimpinan yang beragama hindu yang mengambil cuti dengan penyebab yang sama, penting bagi para stafnya untuk memiliki PKO agar tetap disiplin dalam bekerja meski tidak sedang diawasi.

\section{METODE PENELITIAN}

\section{Variabel dan Definisi Operasional}

Penelitian ini menggunakan dua jenis variabel, yaitu: variabel tergantung dan variabel bebas. Variabel tergantung pada penelitian ini adalah perilaku kewargaan organisasi, sedangkan variabel bebasnya adalah kepuasan kerja dan persepsi pada iklim organisasi. Definisi operasional dari masing-masing variabel penelitian adalah sebagai berikut:

$\underline{\text { Perilaku kewargaan organisasi }}$ 
Perilaku kewargaan organisasi adalah bentuk perilaku yang merupakan pilihan dan inisiatif individual, tidak berkaitan dengan sistem reward formal organisasi tetapi dapat meningkatkan efektivitas organisasi. Perilaku kewargaan organisasi tercermin dalam aspek :

1. Perilaku menolong (Altruism)

2. Ketelitian (Conscientiousness)

3. Rasa hormat (Courtesy)

4. Sportif (Sportsmanship)

5. Tanggungjawab keanggotaan (Civic virtue)

Taraf PKO diukur dengan menggunakan skala PKO, semakin tinggi skor total yang diperoleh, maka semakin tinggi taraf PKO.

Kepuasan kerja

Kepuasan kerja adalah sekumpulan perasaaan pegawai baik suka maupun tidak terhadap pekerjaannya yang merupakan hasil interaksi dan persepsi pegawai terhadap lingkungan kerja dan pekerjaanya. Kepuasan kerja terukur dalam aspek :

1. Upah

2. Pekerjaan itu sendiri

3. Kesempatan promosi

4. Penyelia

5. Rekan kerja

Taraf kepuasan kerja diukur dengan skala kepuasan kerja, semakin tinggi skor total kepuasan kerja, maka karyawan semakin puas.

Persepsi terhadap iklim organisasi

Persepsi terhadap iklim organisasi adalah suatu proses mengorganisasi dan mengintrepretasikan kesan atau informasi yang diperoleh oleh pekerja atau anggota organisasi mengenai lingkungan kerja yang akan menentukan sikap dan perilaku mereka terhadap pekerjaanya. Persepsi pada iklim organisasi dapat diukur melalui aspek :

1. Struktur

2.Standar-standar

3. Tanggung jawab

4. Penghargaan

5. Dukungan

6. Komitmen

Taraf persepsi pada iklim organisasi diukur dengan skala persepsi pada iklim organisasi, semakin tinggi skor total yang diperoleh, maka karyawan mempersepsikan iklim organisasi semakin positif.

\section{Responden}

Responden penelitian ini adalah tenaga kerja yang berstatus sebagai pegawai tetap di PT. Garuda Indonesia, (Persero), Tbk. Sehingga sampel penelitian yang digunakan adalah seluruh karyawan tetap PT. Garuda Indonesia yang berjumlah 71 orang.

\section{Tempat dan Waktu Penelitian}

Tempat penelitian ini di Kantor Cabang PT. Garuda Indonesia, (Persero), Tbk. Denpasar, Bali. Penelitian dilaksanakan pada tanggal 30 April 2018 sampai dengan 9 Mei 2018. Penelitian dilakukan terhadap seluruh karyawan tetap PT. Garuda Indonesia (Persero), Tbk., cabang Denpasar. Penyebaran angket dilakukan dengan cara bertemu langsung dengan responden penelitian. Skala yang digunakan dalam pengambilan data terdiri dari empat bagian, yaitu bagian pertama adalah informed consent, bagian kedua adalah surat pernyataan persetujuan, ketiga adalah identitas diri dan petunjuk pengisian, bagian terakhir adalah skala yang akan dijawab oleh subjek.

\begin{abstract}
Alat Ukur
Alat ukur penelitian yang digunakan untuk mengumpulkan data pada penelitian ini, yaitu :

Skala perilaku kewargaan organisasi yang dikemukakan oleh Simarmata (dalam Veera, 2014) dengan koefisien reliabilitas adalah 0.965, sehingga hasil total skor yang diperoleh masing-masing responden akan menentukan taraf perilaku kewargaan organisasi karyawan dengan semakin tinggi skor total perilaku kewargaan organisasi, maka kecenderungan untuk menunjukan perilaku tersebut semakin tinggi.
\end{abstract}

Skala pengukuran kepuasan kerja menggunakan dimensi yang dikemukakan oleh Gibson, Ivancevich dan Donnely (1993), yaitu skala untuk uji validitas dengan menggunakan corrected item-Total Correlation dan uji reliabilitas dengan menggunakan Cronbach Alpha, sehingga hasil total skor yang diperoleh masing-masing responden akan menentukan taraf kepuasan kerja karyawan dengan semakin tinggi skor total kepuasan kerja, maka karyawan semakin puas.

Skala pengukuran persepsi pada iklim organisasi dalam penelitian ini menggunakan dimensi yang dikemukakan oleh Stringer untuk menunjukkan taraf persepsi pada iklim organisasi. Skala yang digunakan adalah hasil modifikasi skala yang digunakan oleh Veera (2014). Koefisien reliabilitas dengan menggunakan koefisien Alpha Cronbach pada skala iklim organisasi sebesar 0.937, sehingga hasil total skor yang diperoleh masing-masing responden akan menentukan taraf persepsi pada iklim organisasi dengan semakin tinggi skor total persepsi pada iklim organisasi, maka karyawan mempersepsikan iklim organisasi semakin positif.

\section{Metode pengumpulan data}

Metode pengumpulan data dalam penelitian ini menggunakan metode skala yakni berupa kuesioner/angket dan Studi dokumentasi. Pada pengumpulan data dengan kuesioner/angket, responden akan menjawab seperangkat pernyataan tertulis yang terdiri dari tiga jenis skala yaitu skala 
Kepuasan Kerja, Persepsi pada Iklim Organisasi dan Perilaku Kewargaan Organisasi. Sedangkan Studi dokumentasi adalah dengan mencari data mengenai hal-hal berupa catatan, buku, atau laporan yang ada di perusahaan seperti data kepegawaian, dan struktur organisasi dalam rangka mendukung hasil penelitian agar lebih relevan (Arikunto, 2006).

\section{Teknik Analisis Data}

Teknik analisis data dalam penelitian ini menggunakan analisis Regresi Berganda dengan bantuan program SPSS 22.0 for Windows. Sebelum melakukan analisis data penelitian dilakukan uji asumsi data yang mencakup uji normalitas, uji linearitas dan uji multikolinearitas. Uji normalitas dilakukan dengan menggunakan uji Kolmogorov-Smirnov pada program SPSS 22.0 for Windows. Uji linearitas dilakukan dengan menggunakan Test of Linearity pada program SPSS 22.0 for Windows, sedangkan uji multikolinearitas dilakukan dengan menggunakan nilai Variance Inflation Factor (VIF) dan nilai Tolerance pada program SPSS 22.0 for Windows.

\section{HASIL PENELITIAN}

\section{Karakteristik Subjek}

Subjek dalam penelitian ini adalah seluruh pegawai yang bestatus sebagai karyawan tetap PT. Garuda Indonesia (Persero), Tbk., cabang Denpasar yang berjumlah 71 orang.

Karakteristik subjek berdasarkan usia menyatakan bahwa sebagian besar karyawan berusia antara 41-50 tahun yakni sebanyak 44 orang dari 71 orang karyawan dengan persentase $62 \%$. Karakteristik subjek berdasarkan jenis kelamin menyatakan bahwa karyawan berjenis kelamin laki-laki sebanyak 39 orang dari 71 orang karyawan dengan persentase $54,93 \%$. Karakteristik subjek berdasarkan lama kerja menyatakan bahwa sebagian besar karyawan telah bekerja selama 21-30 tahun sebanyak 55 orang dari 71 orang karyawan dengan persentase $77,46 \%$.

\section{Deskripsi dan Kategorisasi Data Penelitian}

Hasil deskripsi data penelitian yaitu kepuasan kerja, persepsi pada iklim organisasi dan perilaku kewargaan organisasi dapat dilihat pada tabel 1 (terlampir).

Hasil deskripsi statistik kepuasan kerja pada tabel 1 menunjukkan bahwa i mean teoretis sebesar 65 dan mean empiris sebesar 84,28. Hal ini menunjukkan perbedaan yang signifikan antara mean empiris dan mean teoretis. Mean empiris yang diperoleh lebih besar dari mean teoretis (mean empiris $>$ mean teoretis) menghasilkan sebuah kesimpulan bahwa subjek memiliki taraf kepuasan kerja yang tinggi.
Hasil deskripsi statistik persepsi pada iklim organisasi pada tabel 1 menunjukkan bahwa persepsi pada iklim organisasi memiliki mean teoretis sebesar 71 dan mean empiris sebesar 87,68. Hal ini menunjukkan perbedaan yang signifikan antara mean empiris dan mean teoretis. Mean empiris yang diperoleh lebih besar dari mean teoretis (mean empiris $>$ mean teoretis) menghasilkan sebuah kesimpulan bahwa subjek memiliki persepsi yang positif pada iklim organisasi.

Hasil deskripsi statistic perilaku kewargaan organisasi pada tabel 1 menunjukkan bahwa PKO memiliki mean teoretis sebesar 71 dan mean empiris sebesar 75,70. Hal ini menunjukkan bahwa subjek memiliki taraf PKO yang tinggi.

\section{Uji Asumsi Penelitian}

Hasil uji normalitas di atas dapat diketahui bahwa semua variabel penelitian memiliki nilai residual lebih besar dari 0,05 (sig $>0,05)$, sehingga dapat disimpulkan bahwa data penelitian berdistribusi normal.

Sebaran data variabel kepuasan kerja berdasarkan hasil uji normalitas pada tabel 2 (terlampir) menunjukkan bahwa data pada variabel kepuasan kerja berdistribusi normal dengan nilai signifikansi $0,331 \quad(\mathrm{p}>0,05)$. Persepsi pada iklim organisasi berdasarkan hasil uji normalitas pada tabel 2 menunjukkan bahwa variabel persepsi pada iklim organisasi berdistribusi normal dengan nilai signifikansi 0,899 ( $>00,05)$. Perilaku kewargaan organisasi berdasarkan hasil uji normalitas pada tabel 2 menunjukkan bahwa data pada variabel PKO berdistribusi normal dengan nilai signifikansi $0,564(\mathrm{p}>0,05)$.

Uji linearitas dilakukan untuk mengetahui apakah dua variabel mempunyai hubungan linear atau tidak secara signifikan. Dua variabel dikatakan memiliki hubungan linear apabila signifikansi Deviation from Linearity $>0,05$ (Azwar, 2013). Data hasil uji linieritas dapat dilihat pada tabel 3 (terlampir).

Hasil uji linearitas pada tabel 3 dapat diketahui bahwa semua variabel memiliki nilai signifikansi Deviation from Linearity yang lebih besar dari $0,05(\mathrm{sig}>0,05)$ dan signifikansi Liniearity sebesar 0,000 (sig<0,05), hal ini menunjukkan bahwa semua variabel penelitian adalah linier, artinya bahwa terdapat hubungan antara kepuasan kerja dengan perilaku kewargaan organisasi dan persepsi pada iklim organisasi dengan perilaku kewargaan organisasi.

Uji multikolinieritas dilakukan untuk mengetahui besarnya kolerasi antar variabel bebas dalam penelitian ini. Jika terjadi korelasi, maka dinamakan terdapat 


\section{K. M. TRISNAYANI \& NAOMI VEMBRIATI}

masalah multikolinieritas. Untuk mendeteksi ada tidaknya multikolinieritas dapat dilihat pada nilai tolerance dan VIF. Apabila nilai toleransi di atas 0,1 dan nilai VIF di bawah 10 maka tidak terjadi multikolinieritas (Ghozali, 2011). Hasil uji multikolinieritas untuk model regresi pada penelitian ini disajikan pada tabel 4 (terlampir). Dari tabel 4 terlihat bahwa semua variabel mempunyai nilai toleransi di atas 0,1 dan nilai VIF di bawah 10 , sehingga dapat disimpulkan bahwa model regresi pada penelitian ini tidak terjadi multikolinieritas.

Berdasarkan hasil dari uji normalitas, linearitas dan multikolinieritas dapat disimpulkan bahwa data pada penelitian ini berdistribusi normal, memiliki hubungan yang linier dan tidak terjadi multikolinieritas.

\section{Uji Hipotesis}

Pengujian hipotesis dilakukan untuk menguji hipotesis yang diajukan. Hipotesis yang diajukan dalam penelitian ini terkait variabel kepuasan kerja dan persepsi pada iklim organisasi terhadap perilaku kewargaan organisasi. Analisis regresi berganda dipilih untuk menganalisis pengajuan hipotesis dalam penelitian ini. Berikut ini hasil analisis regresi berganda yang dilakukan dengan menggunakan program SPSS 22.00 for Windows (tabel terlampir).

Hasil uji regresi berganda anatara kepuasan kerja dan persepsi pada iklim organisasi terhadap PKO menunjukkan koefisien regresi $\mathrm{R}$ sebesar 0,710 sehingga mendapatkan nilai $\mathrm{R}$ Square sebesar 0,505 yang berarti bahwa diperoleh sumbangan efektif dari variabel kepuasan kerja dan persepsi pada iklim organisasi terhadap perilaku kewargaan organisasi sebesar 50,5\% sementara $49,5 \%$ adalah faktor lain yang tidak diteliti dalam penelitian ini.

Hasil uji regresi berganda pada tabel 6 (terlampir) menunjukkan F hitung sebesar 34,626 dan signifikani sebesar $0,000(\mathrm{p}<0,05)$. Kesimpulannya adalah bahwa kepuasan kerja dan persepsi pada iklim organisasi secara bersama-sama berpengaruh terhadap perilaku kewargaan organisasi.

Hasil uji regresi berganda pada tabel 7 (terlampir) menunjukkan bahwa kepuasan kerja memiliki nilai $\mathrm{t}$ sebesar 1,399 dan signifikansi sebesar 0,166 ( $p>0,05)$ sehingga kepuasan kerja tidak berpengaruh secara signifikan terhadap perilaku kewargaan organisasi. Hasil uji regresi berganda untuk persepsi pada iklim organisasi memiliki nilai $t$ sebesar 5,682 dan signifikansi sebesar $0,000 \quad(\mathrm{p}<0,05)$ sehingga dapat disimpulkan bahwa persepsi pada iklim organisasi berpengaruh secara signifikan terhadap perilaku kewargaan organisasi.
Hasil uji regresi berganda pada tabel 7 dapat memprediksi taraf perilaku kewargaan organisasi dari masing-masing subjek dengan melihat persamaan garis regresi sebagai berikut :

$\mathrm{Y}=7,139+0,264 X_{1}+0,528 X_{2}$

Keterangan :

Y : Perilaku Kewargaan Organisasi

$X_{1} \quad:$ Kepuasan Kerja

$X_{2} \quad$ : Persepsi pada Iklim Organisasi

a. Konstanta sebesar 7,139 menyatakan bahwa jika tidak ada penambahan atau peningkatan skor pada kepuasan kerja dan persepsi pada iklim organisasi maka taraf perilaku kewargaan organisasi sebesar 7,139.

b. Koefisien regresi $X_{1}$ sebesar 0,264 menyatakan bahwa pada setiap penambahan 0,264 satuan skor kepuasan kerja maka akan terjadi peningkatan pada taraf perilaku kewargaan organisasi.

c. Koefisien regresi $X_{2}$ sebesar 0,528 menyatakan bahwa pada setiap penambahan 0,528 satuan skor persepsi pada iklim organisasi maka akan terjadi peningkatan pada taraf perilaku kewargaan organisasi.

Ringkasan hasil uji regresi berganda pada hipotesisi mayor dan minor pada penelitian ini dirangkum pada tabel 8 (terlampir).

\section{PEMBAHASAN DAN KESIMPULAN}

Berdasarkan hasil penelitian yang telah dilakukan dan dianalisis dengan menggunakan teknik analisa regresi berganda dapat diketahui bahwa kepuasan kerja dan persepsi pada iklim organisasi berpengaruh terhadap perilaku kewargaan organisasi pada karyawan PT. Garuda Indonesia (Persero), Tbk. Hal ini dapat dilihat dari hasil uji regresi linier berganda yang menunjukkan signifikansi sebesar $0,000(p<0,05)$ yang berarti bahwa kepuasan kerja dan persepsi pada iklim organisasi secara bersama-sama memiliki pengaruh terhadap kemunculan perilaku kewargaan organisasi. Jika karyawan memiliki kepuasan kerja yang tinggi dan mempersepsikan iklim organisasinya secara positif, maka akan muncul PKO tersebut pada diri karyawan. Koefisien determinasi menunjukkan persentase sebesar 0,505 yang berati bahwa variabel kepuasan kerja dan persepsi pada iklim organisasi menentukan perilaku kewargaan organisasi sebesar $50,5 \%$ sedangkan $49,5 \%$ sisanya dipengaruhi oleh faktor lain. 
Pada hasil uji regresi nilai koefisien beta berstandar untuk kepuasan kerja sebesar 0,150 sedangkan persepsi pada iklim organisasi sebesar 0,609, sehingga dapat diartikan bahwa persepsi pada iklim organisasi lebih berpengaruh terhadap munculnya PKO bila dibandingkan dengan kepuasan kerja. Pernyataan tersebut didukung dengan nilai signifikansi kepuasan kerja yang hanya sebesar $0,166(\mathrm{p}>0,05)$ yang berarti bahwa kepuasan kerja tidak berpengaruh terhadap PKO. Berbeda dengan nilai signifikansi persepsi pada iklim organisasi yaitu sebesar $0,000(\mathrm{p}<0,05)$ yang berarti bahwa variabel persepsi pada iklim organisasi berpengaruh terhadap PKO karyawan. Hal ini dikarenakan kepuasan kerja bersifat individual yang artinya kepuasan kerja dirasakan oleh masing-masing individu berdasarkan persepsi mereka terhadap pekerjaannya dan setiap individu merasakan tingkat kepuasan yang berbeda-beda sesuai dengan sistem nilai yang berlaku pada dirinya (Robbins, 2009). Berbeda dengan PKO yang merupakan budaya kolektifis, artinya bahwa perilaku tersebut bersifat pilihan dan merupakan tindakan sukarela dari karyawan. Perilaku kewargaan organisasi diartikan sebagai suatu perilaku yang merupakan pilihan dan inisiatif individual yang dapat meningkatkan produktivitas organisasi namun tidak termasuk kedalam deskripsi pekerjaan sehingga jika tidak ditampilkan maka tidak akan diberi hukuman (Organ, 1997).

Hasil penelitian menunjukkan bahwa perpsesi pada iklim organisasi berpengaruh secara signifikan terhadap perilaku kewargaan organisasi yang ditunjukkan dengan nilai signifikansi sebesar 0,000 $(\mathrm{p}<0,05)$. Hal ini berarti bahwa ketika karyawan mempersepsikan secara positif iklim organisasinya maka akan memunculkan perilaku kewargaan organisasi pada diri karyawan. Hal ini sejalan dengan penelitian yang dilakukan oleh Prihatsanti dan Dewi (2010) yang membuktikan bahwa ketika individu memiliki persepsi yang positif pada iklim organisasi maka secara sukarela anggota organisasi akan memberikan kontribusi dalam usaha-usaha pencapaian tujuan organisasi. Penelitian ini menegaskan iklim organisasi menunjukkan gaya hidup orang dari sebuah organisasi, dengan menciptakan iklim organisasi yang kondusif akan menghasilkan perilaku kewargaan organisasi. Semakin karyawan mempersepsikan iklim organisasi di perusahaanya semakin kondusif, semakin tinggi pula PKO para karyawan tersebut. Sebaliknya, jika iklim organisasi dipersepsikan tidak kondusif maka semakin rendah pula PKO karyawan tersebut.

Kondisi ini sesuai dengan pendapat Bersona dan Avilio (dalam Prihatsanthi \& Dewi, 2010) yang menemukan dalam beberapa penelitian bahwa salah satu faktor penting yang membentuk PKO adalah iklim organisasi. Menurut Wang (dalam Prihatsanthi \& Dewi, 2010) menambahkan PKO merupakan perilaku yang mendukung performa kerja melalui peningkatan iklim organisasi, jika iklim organisasi dipersepsikan secara positif oleh anggota organisasi, maka secara sukarela anggota organisasi akan memberikan kontribusi dalam usaha-usaha pencapaian tujuan organisasi. Perilaku kewargaan organisasi sebagai kontribusi informal memberikan pilihan kepada anggota organisasi dalam hal ini karyawan secara bebas memilih untuk memberikan atau tidak memberikan kontribusi tanpa adanya sangsi atau insentif (Gadot, 2007). Hubungan antara iklim organisasi (iklim perusahaan) dengan PKO, yaitu jika iklim organisasi dipersepsikan secara positif maka PKO akan muncul (Gadot, 2007).

Penelitian oleh Appelbaum (dalam Kusumajati, 2014) menyatakan bahwa karyawan dikatakan mempunyai PKO yang baik jika menunjukkan beberapa perilaku diantaranya membuat pernyataan konstruktif tentang organisasi dan kelompok kerjanya, menghindari konflik yang tidak perlu, membantu karyawan lain dalam satu tim, mengajukan diri untuk pekerjaan ekstra, menghormati semangat dan isi peraturan yang dimiliki organisasi, dan dengan besar hati mentolerir kerugian dan gangguan terkait pekerjaan yang kadang terjadi. Berdasarkan hasil wawancara yang diperoleh,, karyawan PT. Garuda Indonesia (Persero) Tbk cabang Denpasar menunjukkan PKO yang tinggi, diantaranya saling membantu sesama rekan kerja, disiplin tanpa pengawasan dan berusaha sebaik mungkin untuk kemajuan perusahaan, menghindari konflik dan menjaga keharmonisan sesama rekan kerja, toleransi atas ketidaknyamanan yang terjadi tanpa mengeluh, dan berpartisipasi aktif dalam seluruh kegiatan yang diadakan perusahaan. Hal ini merupakan bukti empiris bahwa para karyawan PT. Garuda Indonesia (Persero) Tbk cabang Denpasar menunjukkan PKO saar bekerja. Hasil penelitian menunjukkan bahwa ketika karyawan merasakan kepuasan kerja, didukung dengan persepsi positif terhadap iklim organisasi maka akan muncul PKO pada karyawan.

Berdasarkan hasil penelitian dan analisis data yang telah dilakukan maka dapat ditarik kesimpulan bahwa : 1. Kepuasan kerja dan persepsi pada iklim organisasi secara bersama-sama berkontribusi secara signifikan terhadap kemunculan perilaku kewargaan organisasi.

2. Kepuasan kerja tidak memiliki kontribusi yang signifikan terhadap tinggi rendahnya perilaku kewargaan organisasi, artinya bahwa tinggi rendahnya perilaku kewargaan organisasi tidak dapat dijelaskan oleh tingkat 


\section{K. M. TRISNAYANI \& NAOMI VEMBRIATI}

kepuasan kerja pegawai. Hal ini dapat terjadi ketika faktor keadilan diperhitungkan.

3. Persepsi pada iklim organisasi memiliki kontribusi yang positif dan signifikan terhadap tinggi rendahnya perilaku kewargaan organisasional. Dengan demikian tinggi rendahnya perilaku kewargaan organisasional dapat dijelaskan oleh persepsi pada iklim organisasi.

4. Kepuasan kerja karyawan PT. Garuda Indonesia (Persero), Tbk. tergolong sangat tinggi karena berdasarkan kategorisasi 98,6\% responden memiliki taraf kepuasan kerja yang sangat tinggi.

5. Persepsi pada iklim organisasi karyawan PT. Garuda Indonesia (Persero) Tbk. sebagian besar menunjukkan nilai yang sangat tinggi karena berdasarkan kategorisasi 69,01\% subjek, berarti bahwa sebagian besar karyawan memiliki persepsi positif pada iklim organisasi.

6. Perilaku kewargaan organisasi karyawan PT. Garuda Indonesia (Persero), Tbk. tergolong sangat tinggi berdasarkan kategorisasi $77,46 \%$ subjek memiliki taraf perilaku kewargaan organisasi yang sangat tinggi.

Berdasarkan kesimpulan tersebut maka dapat disampaikan saran penelitian untuk perusahaan, apabila ingin memunculkan dan mempertahankan perilaku tersebut maka perlu untuk memunculkan persepsi positif karyawan terhadap iklim organisasi. Sedangkan bagi karyawan diharapkan dapat mempertahankan PKO sehingga tujuan perusahaan dapat dicapai dengan efektif dan efisien. Hubungan yang baik dengan rekan kerja juga dapat terus ditingkatkan sehingga kinerja tim dan situasi kerja semakin kondusif. Karyawan diharapkan dapat membantu rekan kerja yang sedang kelelahan, hal ini dapat menciptakan rasa solidaritas sesama karyawan. Karyawan juga diharapkan dapat mempertahankan dan meningkatkan tanggung jawab yaitu menjalankan tugas dengan baik, ramah dan sabar menangani customers guna terciptanya target perusahaan.

Penelitian ini dapat dilakukan kembali dengan subjek penelitian yang berbeda serta dengan kuisioner yang valid dan reliabel. Berdasarkan nilai koefisien determinasi untuk kepuasan kerja dan iklim organisasi yang hanya memiliki nilai sebesar $50,5 \%$, maka masih terdapat variabel lain yang mempengaruhi perilaku kewargaan organisasi sehingga bagi penelitian lanjutan diharapkan menambahkan variabel selain kepuasan kerja dan persepsi iklim organisasi yang berpengaruh terhadap perilaku kewargaan organisasi. Selain itu disarankan untuk melakukan penelitian dengan ruang lingkup atau objek yang lebih luas menjadi keefektifan organisasi yaitu dengan membandingkan keefektifan satu organisasi dengan organisasi lain yang sejenis. Penelitian ini dilakukan pada perusahaan yang memiliki karyawan dengan PKO sangat tinggi, sehingga diharapkan bagi penelitian selanjutnya untuk melakukan penelitian pada organisasi dengan PKO yang rendah untuk membuktikan apakah benar persepsi pada iklim organisasi memang berkontribusi terhadap kemunculan PKO karyawan.

\section{DAFTAR PUSTAKA}

Anonim. (2018). Diunduh dari https://www.garudaindonesia.com/id/id/corporate-partners/companyprofile/about/index.page?

Arikunto, S. (2006). Metodologi penelitian. Yogyakarta: Bina Aksara.

Azwar, S. (2013). Metode penelitian (Edisi ke-1). Yogyakarta: Pustaka Pelajar.

Gadot, E.V. (2007). Group-level Organizational citizenship behavior in the education system: A scale reconstruction and validation. Educational administration quarterly, 43(4), 462-493. doi: 10.1177/0013161X07299435.

Ghozali, I. (2011). Aplikasi analisis multivariate dengan program SPSS. Semarang: Badan Penerbit Universitas Diponegoro.

Gibson, J. L., Ivancevich, J.M., \& Donnelly, J. H. (1993). Organisasi: Perilaku, struktur, proses (Edisi ke5, Jilid 1), Jakarta: Erlangga.

Gronross. (2000). Service management and marketing. West Sussex: John Wiley and Sons LTD.

Gunawan, J.S., Solang, P.D., \& Kartika, E.W. (2013). Organizational citizenship behavior yang berpengaruh pada kinerja karyawan dan kepuasan konsumen di Hotel Sheraton Surabaya. Junal Hospitality dan Manajemen Jasa, 1(2), 120-133.

Kusumajanti, D.A. (2014). Organizational citizenship behavior (OCB) karyawan pada perusahaan. Humaniora, 5(1), 62-70. Diunduh dari http://research-

dashboard.binus.ac.id/uploads/paper/document/p ublication/Proceeding/Humaniora/Vol.\%205\%20 No.\%201\%20April\%202014/7 CB Dian\%20An ggraini\%20Kusumajati OK.pdf

Organ, D.W. (1988). Organizational citizenship behavior: The good soldier syndrome. Lexington, MA: Lexington Books.

Organ, D.W. (1997). Organizational citizenship behavior: It's construct clean-up time. Human Performance, 2(10), 85-97. Diunduh dari https://www.researchgate.net/profile/Dennis_Org an/publication/247083204_Organizational_Citize nship_Behavior_It\%27s_Construct_CleanUp_Time/links/540a203d0cf2d8daaabfa0ae/Orga nizational-Citizenship-Behavior-Its-ConstructClean-Up-Time.pdf?origin=publication_detail

Organ, D.W., Podsakoff, P.M., \& MacKenzie, S.B. (2006). Organizational citizenship behavior :Its nature, 
antecendents, and consequence. California: Sage Publications, Inc.

Prihatsanti, U., \& Dewi. K.S. (2010). Hubungan antara iklim organisasi dan organizational citizenship behavior pada Guru SD Negeri di Kecamatan Mojolaban Sukoharjo. Jurnal Psikologi Undip, 7(1), 11-17. Diunduh dari http://psikologi.undip.ac.id/unikaprihatsanti-s-psima/

Robbins, S. P., \& Judge, T.A. (2008). Perilaku organisasi (Buku 2). Jakarta: Salemba Empat.

Saptoani, A. (2011). Organizational citizenship behavior tenaga pendidik. Malang : Bayu Media.

Soegandhi, V.M., Sutanto, E.M., \& Setiawan, R. (2013). Pengaruh loyalitas kerja dan kepuasan kerja. Agora, 1(1), 1-45.

Ttitisari, P. (2014). Peranan organizationa citizenship behavior (OCB) dalam meningkatkan kinerja karyawan. Jakarta: Mitra Wacana Media.

Triyanto, A. (2009). Organizational citizenship behavior (OCB) dan pengaruhnya terhadap keinginan keluar dan kepuasan kerja Karyawan. Jurnal Manajemen, 7(4), 1-13.

Trisnayani, K.M. (2017). Peranan kepuasan kerja dan persepsi iklim organisasi karyawan PT. Garuda Indonesia (Persero) Tbk cabang Denpasar terhadap perilaku kewargaan organisasi (Naskah tidak dipublikasi). Program Studi Psikologi, Fakultas Kedokteran, Universitas Udayana, Denpasar.

Udayana, P., \& Suwandana, M. (2017). Pengaruh kepuasan kerja dan komitmen organisasional terhadap organizational citizenship behavior. E-Jurnal Manajemen Unud, 6(7), 3570-3594.

Veera, Aninditha. (2015). Hubungan antara Iklim Organisasi dengan Perilaku Kewargaan Organisasi pada Karyawan di Perusahaan Ritel. Jurnal Psikologi Udayana, 2(1), 25-37.

Waspodo, A., \& Minandaniati, L. (2012). Pengaruh kepuasan kerja dan iklim organisasi terhadap organitational citizenship behavior (OCB) karyawan PT. Tribus Swadaya. Jurnal Riset Manajemen Sains Indonesia (JRMSI). 3(1), 1-16.

Wulandari, P. (2015). Pengaruh kepuasan kerja dan komitmen organisasi terhadap Organizational Citizenship Behavior pada perawat rumah sakit islam Yogyakarta. (Skripsi tidak dipublikasikan), Fakultas Ekonomi, Universitas Negeri Yogyakarta, Yogyakarta.

Yuniar, Y., Nurtjahjanti, H., \& Rusmawati, D. (2011). Hubungan antara kepuasan kerja dan esiliensi dengan organizational citizenship behavior (OCB) pada karyawan kantor pusat PT. BPD Bali. Jurnal Psikologi Undip, 9(1), 11-20.

Zhang, D. (2011). Organisational citizenship behavior. Diunduh dari https://cdn.auckland.ac.nz/assets/psych/about/ourpe
ople/documents/Deww\%20Zhang\%20\%20Organisa tional\%20Citizenship $\% 20$ Behaviour $\% 20 \% 20$ White \%20Paper.pdf) 


\section{LAMPIRAN}

Tabel 1

Deskripsi Statistik Data Penelitian

\begin{tabular}{|c|c|c|c|c|c|c|c|}
\hline Variabel & $\mathrm{N}$ & $\begin{array}{l}\text { Mean } \\
\text { Teoretis }\end{array}$ & $\begin{array}{l}\text { Mean } \\
\text { Empiris }\end{array}$ & $\begin{array}{l}\text { Std. Deviasi } \\
\text { Teoretis }\end{array}$ & $\begin{array}{l}\text { Std. Deviasi } \\
\text { Empiris }\end{array}$ & $\begin{array}{l}\text { Sebaran } \\
\text { Teoretis }\end{array}$ & $\begin{array}{l}\text { Sebaran } \\
\text { Empiris }\end{array}$ \\
\hline $\begin{array}{l}\text { Kepuasan } \\
\text { Kerja }\end{array}$ & 71 & 60 & 84,28 & 12 & 3,21 & $24-96$ & $78-92$ \\
\hline $\begin{array}{l}\text { Persepsi pada } \\
\text { Iklim } \\
\text { Organisasi }\end{array}$ & 71 & 65 & 87,68 & 13 & 6,51 & $26-104$ & 74-101 \\
\hline $\begin{array}{l}\text { Perilaku } \\
\text { Kewargaan } \\
\text { Organisasi }\end{array}$ & 71 & 55 & 75,70 & 11 & 5,65 & $22-88$ & $63-87$ \\
\hline $\begin{array}{l}\text { Keterangan } \\
\mathrm{N} \quad \text { : Tota } \\
\text { Std } \quad: \text { Stan }\end{array}$ & ubj & & & & & & \\
\hline
\end{tabular}

Tabel 2

Hasil Uji Normalitas

\begin{tabular}{lll}
\hline Variabel & Signifikasi & Keterangan \\
Kepuasan Kerja & 0,331 & Normal \\
Persepsi pada Iklim Organisasi & 0,899 & Normal \\
PKO & 0,564 & Normal \\
\hline
\end{tabular}

Tabel 3

Hasil Uji Linieritas

\begin{tabular}{llll}
\hline Variabel & $\begin{array}{l}\text { Signifikasi Deviation from } \\
\text { Linearity }\end{array}$ & $\begin{array}{l}\text { Signifikansi } \\
\text { Linearity }\end{array}$ & Keterangan \\
\hline Kepuasan Kerja*PKO & 0,341 & 0,000 & Linear \\
\hline Persepsi pada Iklim Organisasi*PKO & 0,374 & 0,000 & Linear \\
\hline
\end{tabular}

Tabel 4.

Hasil Uji Multikolinearitas

\begin{tabular}{llll}
\hline Variabel & Tolerance & VIF & Kesimpulan \\
\hline KepuasanKerja & 0,633 & 1,579 & Tidak terjadi multikolinearitas \\
\hline $\begin{array}{l}\text { Persepsi pada Iklim } \\
\text { Organisasi }\end{array}$ & 0,633 & 1,579 & Tidak terjadi multikolinieritas \\
\hline
\end{tabular}


Tabel 5

Hasil Uji Regresi Berganda Kepuasan Kerja dan Persepsi Iklim Organisasi terhadap PKO

\begin{tabular}{lcc}
\hline \multicolumn{1}{c}{ Variabel } & R & R Square \\
\hline $\begin{array}{l}\text { Kepuasan kerja dan Persepsi pada Iklim } \\
\text { Organisasi terhadap PKO }\end{array}$ & 0,710 & 0,505 \\
\hline
\end{tabular}

Tabel 6 .

Hasil Uji F

\begin{tabular}{lll}
\hline Model & F & Sig. \\
\hline Regression & 34,626 & $0,000^{\mathrm{a}}$ \\
\hline
\end{tabular}

Tabel 7

Hasil Uji t

\begin{tabular}{lcccc}
\hline \multicolumn{1}{c}{ Model } & $\begin{array}{c}\text { Unstandardized } \\
\text { Coefficients } \\
\text { B }\end{array}$ & $\begin{array}{c}\text { Standardized } \\
\text { Coefficients } \\
\text { Beta }\end{array}$ & $\mathrm{t}$ & Sig. \\
\hline Constant) & 7,139 & 0,150 & 0,560 & 0,578 \\
Kepuasan Kerja & 0,264 & 0,609 & 1,399 & 0,166 \\
Persepsi pada Iklim Organisasi & 0,528 & 5,682 & 0,000 \\
\hline
\end{tabular}

Tabel 8

Rangkuman Hasil Uji Hipotesis Penelitian

\begin{tabular}{llc}
\hline No & \multicolumn{1}{c}{ Hipotesis } & Hasil \\
\hline 1. & $\begin{array}{l}\text { Kepuasan kerja dan persepsi pada iklim organisasi berpengaruh positif terhadap } \\
\text { perilaku kewargaan organisasi karyawan PT. Garuda Indonesia (Persero), Tbk. (Mayor) }\end{array}$ & Diterima \\
\hline 2. & $\begin{array}{l}\text { Kepuasan kerja berpengaruh terhadap perilaku kewargaan organisasi karyawan PT. } \\
\text { Garuda Indonesia (Persero), Tbk. (Minor) }\end{array}$ & Ditolak \\
\hline 3. & $\begin{array}{l}\text { Persepsi pada iklim organisasi berpengaruh terhadap perilaku kewargaan organisasi } \\
\text { karyawan PT. Garuda Indonesia (Persero), Tbk. (Minor) }\end{array}$ & Diterima \\
& & \\
\hline
\end{tabular}

